\title{
A MOTIVATION OF GRADE 11 STUDENTS IN STUDYING ORAL COMMUNICATION: A GUIDE TO CURRICULUM DEVELOPERS AND TEACHERS
}

\author{
Eloisa Rosel-Espeńa, \\ MAT, LPT, Department of Education \\ Congressional Integrated High School, Dasmarinas City, Cavite, Philippines
}

\begin{abstract}
Purpose: Aims to determine students' motivation in studying/learning Oral Communication and students' own learning styles in studying/ learning Oral Communication.

Design/ Methodology/ Approach: The study is qualitativedescriptive in nature. The respondents were all senior high school students in grade 11 of EIM (Electronic Installation Management), CBF (Culinary, Baking and Food Beverages), ABM (Accountacy and Business Management) and CSS (Computer System Servicing) of Congressional Integrated High School. A purposive sampling and survey conducted to collect data.

Findings: It was found out that students' amotivation in studying the subject and learning the English language is because of the two important factors of speaking: grammatical error and vocabulary; which eventually have them lack of confidence to speak. On the other hand, it was also found out that interesting activities using technology made them more interested to study which they also use when they study in their own at home or even at the school.

Research Limitation: The generalization of the research is considering the respondents. Results are applicable for Grade 11 students of Congressional Integrated High School only.

Originality/ Value: The study will help the teachers, syllabus and curriculum designers to focus on approaches and strategies that would motivate students more in studying the subject and learning the English language. New strategies and techniques were highly recommended and suggested.
\end{abstract}

Types of Approach: Descriptive-Qualitative/ Action Research.

Keywords-Amotivation, Learning Styles, TraditionalConventional Approach

\section{INTRODUCTION}

In Philippine Education, studying English language is one of the most important subjects. This, in fact, consider as the Second Language (ESL) in the country. In similar with the other countries, "English is required subject or even medium of instruction in their basic and higher education curriculum" (Jenkins, 2013 in Lucas, et.al., 2016).

One of the macro skills that a student should pass in the Senior High School is the Oral Communication subject. Oral Communication is one of the core subjects which offer in all strands of Grade 11 for English subject. It has been implemented to secure the learners' speaking intelligibility and ability when they are already in their chosen path (college, business and workplace) which will be ready in facing the real- life situations. Speaking is one of the important macro skills to have effective communication. Zaremba (2006, in Boonkit 2010) pointed out "a study indicating that speaking skills or communication skills were usually placed ahead of work experience, motivation, and academic credentials as criteria for new recruitment for employment". Motivation is a factor that would help students in studying the language in "internal process that activates, guides and maintains behavior over time (Eccles, 2002 in Redzuan, et. al., n.d.)". Some motivational factors would be instrumental and integrative. Whereas, "Integrative motivation which typically underlies successful acquisition of a wide range of registers and a native like pronunciation (Finega, 1999) and Instrumental motivation which is more utilitarian because of meeting the requirements for school or university graduation, applying for a job, requesting higher payment based on language ability, reading technical materials, working as interpreters, and moving to a higher social status (in Shirbagi, 2010)." These two factors of motivation that made also the students as their main reasons to study the language.

On the other hand, amotivation or the absence of different motivations (Lucas, et.al., 2016) still makes it a hard time to the student to study the language particularly in speaking or oral communication.

"...Amotivation is defined as a state in which individuals cannot perceive a relationship between their behavior and that behavior's subsequent outcome; instead, the outcomes 


\section{International Journal of Engineering Applied Sciences and Technology, 2020 \\ Vol. 5, Issue 4, ISSN No. 2455-2143, Pages 101-107 \\ Published Online August 2020 in IJEAST (http://www.ijeast.com)}

are perceived to be determined by factors

beyond their control."

And because of being not knowing the outcome the students become more amotivated as they think of a possible negative outcome and would not gain any success of being a good in the subject. Thus, there are also some factors that a teacher, curriculum developers and administrators to look out when it comes to the absence of motivation in studying the language.

The study of Shirbagi (2010) which focuses on the motivation and attitudes of students towards English Language Acquisition revealed that Iranian undergraduate students learn a foreign language because they valued more utilitarian instead of integrative motivation. In comparison to the study of Redzuan, et.al. (n.d.) which focused on determining the types of motivation (instrumental and integrative) of the undergraduate students in Engineering course. It was also found out that these undergraduate students basically learned English because of the benefit of traveling overseas which are instrumentally motivated.

In the study of Lucas, et.al. (2016), which aimed "to explore some possible correlation of amotivation in the Asian context, by studying a sample of Filipino students enrolled in a mandatory English language course in university" which used the self-determination theory of Ryan \& Deci, 2000 with the dimensions: value of task-how important learning tasks are in the student's life, ability beliefs-the belief that one does not have the personal ability to execute and complete the required tasks, task characteristics-negative perceptions or attitudes about the tasks and effort beliefs-the belief that they cannot maintain the effort required to complete the tasks. The study found out that "surface approach was positively correlated with all amotivation dimensions and deep approach was negatively correlated with three of these dimensions."

Thus, among other researches there were no researches focusing on finding out the reasons of high school students (specifically Senior High School of different strands) in having absence of motivation (amotivation) when it comes in learning the language in terms of speaking or oral communication. Also, in knowing the students' own learning styles in studying the subject. Most of them tried to identify the students' preferred types of motivation (instrumental and integrative) and only few studied about the amotivation which focused on the approaches of learning (surface and deep) and none given much attention on the students' personal reasons of amotivation and own learning styles in learning the language.

Therefore, since English subjects like Oral Communication may not be the major subject of different strands such as EIM, CBF, ABM and CSS learners and still have to prioritize as this would help them to pursue their dream of being in college, owning a business and working at company. With this, the researcher and teacher of this study focused on determining the students' personal reasons being amotivated in studying the subject and knowing their own learning styles. The researcher decided to conduct the research in her own classes at Congressional Integrated High School. The classes are composed of different strands and sections which presently taking up Oral Communication subject with the researcher. These sections were selected as respondents as they were all taking up the subject.

The researcher aims to determine students' amotivation in studying/ learning Oral Communication/ English language. This is also to determine the unique style of students in learning the subject and language. questions:

Thus, the researcher formulated the following

1) What are the reasons of students in being amotivated in learning the subject/ English language?

2) What are the students' preferred/own learning styles in learning the subject/ English language?

3) How curriculum developers, teachers and administration would help students to be motivated in learning the subject?

\section{METHODOLOGY}

\section{Research Design}

The researcher used the following tools:

1) self-assessment

2) structured interview questionnaire

to determine the students' amotivation of learning the subject/ English and their learning style in studying the subject/ English language. Survey and structured interview were conducted. Simple frequency count was used to analyze the data.

\section{Participants}

The pilot study were conducted during the Oral Communication presentation

of speech in completion to their Final Period. The participants were all senior high school students in grade 11 of EIM (Electronic Installation Management), CBF (Culinary, Baking and Food Beverages), ABM (Accountacy and Business Management) and CSS (Computer System Servicing). There were a total of one hundred sixty seven (167) students, whereas: EIM 11-1 twenty four (24), CBF 11-1 and CBF 11-2 are both forty three (43), CSS 11-1 twenty nine (29) and ABM 11-2 twenty eight (28) students. All sections were presently taking up Oral Communication in Context (CORE Subject) under the class of the researcher of this study. Respondents were composed of mixed males and females and aged from 15-18. Most of the students can speak their own dialect, Filipino and English.

\section{Instruments}

A five-level Likert Scale of Self-Assessment Questionnaire was composed and used during the study. The rating scales used were: 1-Strongly Disagree, 2- Disagree, 3Undecided, 4-Agree and 5-Strongly Agree (see Appendix A). This is use to know the reasons of the students in having absence of motivation in learning the subject/ language. A Structured Interview Questionnaire (see Appendix B) composed of five (5) questions was also used to identify the 
learning styles of each student in studying the subject/English language.

\section{Procedure/ Data Gathering}

The pilot study was held during the Oral Communication presentation of different types of speech in completion to their Final Period. There were all scheduled in the week 19 (October 7-11, 2019) of their respective sessions. The researcher-teacher of this research explains on how to answer the questionnaire. There were all asked to answer the self-assessment questionnaire right after the presentation of the speech of all the students scheduled on that day. The students were able to finish the said questionnaire in about 20-30 minutes. The structured interview was immediately followed. During the interview, the researcher carefully listened and noted the answers of the following students, which were also recorded for reference. The said interview was not able to finish on the first day and continued on the following meeting of the researcher and teacher of the learners. The following meeting as the class was able to finish the presentation of their speech in earlier, the researcher immediately continued the interview.

\section{Data Analysis}

The self-assessment questionnaire which was composed of sixteen (16) items and validated by an English Teacher was analyzed and counted by a simple frequency count. It was computed by average and equivalent percentages to show the rate of each item. These items were created and used to know the students' amotivation in learning the subject/English language.

The structured interview questionnaire was computed through percentages only. This is to find out the students' personal and unique styles in learning the subject/English language. The questionnaire was also formulated to know the students' personal suggestions to be motivated in learning the said subject.

\section{RESULTS AND DISCUSSION}

\section{Self-Assessment Questionnaire}

Table 1 shows the average rating and equivalent percentages of students' self-assessment in their amotivation of learning Oral Communication and English language.

Table 1

Average Rating and Equivalent Percentages of Students' Self Assessment

\begin{tabular}{|c|c|c|c|c|c|c|c|c|c|}
\hline & 1 & & 2 & & 3 & & 4 & & 5 \\
\hline Items & Ave & $\%$ & Ave & $\%$ & Ave & $\%$ & $\begin{array}{l}\text { Av } \\
\text { e. }\end{array}$ & $\%$ & Ave \\
\hline $\begin{array}{l}\text { 1. I cannot } \\
\text { speak fluently. }\end{array}$ & 0.03 & $\begin{array}{l}2.9 \\
9\end{array}$ & $\begin{array}{l}0.0 \\
9\end{array}$ & 8.98 & $\begin{array}{l}0.0 \\
0\end{array}$ & 0.00 & $\begin{array}{l}0.7 \\
2\end{array}$ & $\begin{array}{l}71 . \\
86\end{array}$ & 0.10 \\
\hline $\begin{array}{l}\text { 2. I do not have } \\
\text { enough } \\
\text { vocabulary. }\end{array}$ & 0.02 & $\begin{array}{l}2.4 \\
0\end{array}$ & $\begin{array}{l}0.0 \\
6\end{array}$ & 5.99 & $\begin{array}{l}0.0 \\
1\end{array}$ & 0.60 & $\begin{array}{l}0.7 \\
8\end{array}$ & $\begin{array}{l}77 . \\
84\end{array}$ & 0.09 \\
\hline $\begin{array}{l}\text { 3. I cannot } \\
\text { construct } \\
\text { sentences } \\
\text { correctly. }\end{array}$ & 0.01 & $\begin{array}{l}1.2 \\
0\end{array}$ & $\begin{array}{l}0.2 \\
0\end{array}$ & $\begin{array}{l}19.7 \\
6\end{array}$ & $\begin{array}{l}0.0 \\
1\end{array}$ & 1.20 & $\begin{array}{l}0.6 \\
0\end{array}$ & $\begin{array}{l}59 . \\
88\end{array}$ & 0.18 \\
\hline $\begin{array}{l}\text { 4. I always } \\
\text { have incorrect } \\
\text { grammar. }\end{array}$ & 0.01 & $\begin{array}{l}1.2 \\
0\end{array}$ & $\begin{array}{l}0.0 \\
3\end{array}$ & 2.99 & $\begin{array}{l}0.0 \\
0\end{array}$ & 0.00 & $\begin{array}{l}0.7 \\
8\end{array}$ & $\begin{array}{l}77 . \\
84\end{array}$ & 0.12 \\
\hline $\begin{array}{l}5 . \text { I cannot } \\
\text { understand and } \\
\text { organize my } \\
\text { ideas. }\end{array}$ & 0.01 & $\begin{array}{l}1.2 \\
0\end{array}$ & $\begin{array}{l}0.2 \\
4\end{array}$ & $\begin{array}{l}23.9 \\
5\end{array}$ & $\begin{array}{l}0.0 \\
0\end{array}$ & 0.00 & $\begin{array}{l}0.6 \\
0\end{array}$ & $\begin{array}{l}59 . \\
88\end{array}$ & 0.06 \\
\hline $\begin{array}{l}\text { 6. I find } \\
\text { activities not } \\
\text { interesting. }\end{array}$ & 0.60 & $\begin{array}{l}59 . \\
88\end{array}$ & $\begin{array}{l}0.0 \\
3\end{array}$ & 2.99 & $\begin{array}{l}0.0 \\
1\end{array}$ & 1.20 & $\begin{array}{l}0.3 \\
0\end{array}$ & $\begin{array}{l}29 . \\
94\end{array}$ & 0.03 \\
\hline $\begin{array}{l}7 . \text { I find } \\
\text { activities not } \\
\text { exceed my } \\
\text { abilities. }\end{array}$ & 0.54 & $\begin{array}{l}53 . \\
89\end{array}$ & $\begin{array}{l}0.0 \\
9\end{array}$ & 8.98 & $\begin{array}{l}0.0 \\
0\end{array}$ & 0.00 & $\begin{array}{l}0.2 \\
4\end{array}$ & $\begin{array}{l}23 . \\
95\end{array}$ & 0.06 \\
\hline $\begin{array}{l}8 \text {. I find it } \\
\text { boring. }\end{array}$ & 0.48 & $\begin{array}{l}47 . \\
90\end{array}$ & $\begin{array}{l}0.2 \\
1\end{array}$ & $\begin{array}{l}20.9 \\
6\end{array}$ & $\begin{array}{l}0.0 \\
0\end{array}$ & 0.00 & $\begin{array}{l}0.1 \\
8\end{array}$ & $\begin{array}{l}17 . \\
96\end{array}$ & 0.06 \\
\hline $\begin{array}{l}\text { 9. I don't see } \\
\text { interesting } \\
\text { topics. }\end{array}$ & 0.54 & $\begin{array}{l}53 . \\
89\end{array}$ & $\begin{array}{l}0.1 \\
6\end{array}$ & $\begin{array}{l}16.1 \\
7\end{array}$ & $\begin{array}{l}0.0 \\
0\end{array}$ & 0.00 & $\begin{array}{l}0.1 \\
8\end{array}$ & $\begin{array}{l}17 . \\
96\end{array}$ & 0.12 \\
\hline $\begin{array}{l}\text { 10. I have lack } \\
\text { of confidence } \\
\text { in speaking. }\end{array}$ & 0.00 & $\begin{array}{l}0.0 \\
0\end{array}$ & $\begin{array}{l}0.1 \\
2\end{array}$ & $\begin{array}{l}11.9 \\
8\end{array}$ & $\begin{array}{l}0.0 \\
0\end{array}$ & 0.00 & $\begin{array}{l}0.7 \\
2\end{array}$ & $\begin{array}{l}71 . \\
86\end{array}$ & 0.15 \\
\hline $\begin{array}{l}11 . \text { I feel lazy } \\
\text { in studying the } \\
\text { subject. }\end{array}$ & 0.48 & $\begin{array}{l}47 . \\
90\end{array}$ & $\begin{array}{l}0.1 \\
6\end{array}$ & $\begin{array}{l}16.1 \\
7\end{array}$ & $\begin{array}{l}0.0 \\
0\end{array}$ & $\overline{0.00}$ & $\begin{array}{l}0.3 \\
0\end{array}$ & $\begin{array}{l}29 . \\
94\end{array}$ & 0.06 \\
\hline $\begin{array}{l}\text { 12. I feel like } \\
\text { it just always } \\
\text { the same thing. }\end{array}$ & 0.09 & $\begin{array}{l}8.9 \\
8\end{array}$ & $\begin{array}{l}0.3 \\
7\end{array}$ & $\begin{array}{l}37.1 \\
3\end{array}$ & $\begin{array}{l}0.0 \\
0\end{array}$ & 0.00 & $\begin{array}{l}0.5 \\
1\end{array}$ & $\begin{array}{l}50 . \\
90\end{array}$ & 0.03 \\
\hline $\begin{array}{l}\text { 13. I feel like } \\
\text { not personally } \\
\text { satisfied. }\end{array}$ & 0.03 & $\begin{array}{l}2.9 \\
9\end{array}$ & $\begin{array}{l}0.5 \\
3\end{array}$ & $\begin{array}{l}52.6 \\
9\end{array}$ & $\begin{array}{l}0.0 \\
1\end{array}$ & 1.20 & $\begin{array}{l}0.3 \\
4\end{array}$ & $\begin{array}{l}34 . \\
13\end{array}$ & 0.09 \\
\hline $\begin{array}{l}\text { 14. Oral } \\
\text { Communicatio } \\
\mathrm{n} \text { is not } \\
\text { important in } \\
\text { my chosen } \\
\text { strand. }\end{array}$ & 0.00 & $\begin{array}{l}0.0 \\
0\end{array}$ & $\begin{array}{l}0.7 \\
2\end{array}$ & $\begin{array}{l}71.8 \\
6\end{array}$ & $\begin{array}{l}0.0 \\
3\end{array}$ & 2.99 & $\begin{array}{l}0.1 \\
8\end{array}$ & $\begin{array}{l}17 . \\
96\end{array}$ & 0.02 \\
\hline $\begin{array}{l}\text { 15. I find it no } \\
\text { good reason to } \\
\text { study the } \\
\text { subject. }\end{array}$ & 0.00 & $\begin{array}{l}0.0 \\
0\end{array}$ & $\begin{array}{l}0.9 \\
1\end{array}$ & $\begin{array}{l}91.0 \\
2\end{array}$ & $\begin{array}{l}0.0 \\
0\end{array}$ & 0.00 & $\begin{array}{l}0.0 \\
6\end{array}$ & $\begin{array}{l}5.9 \\
9\end{array}$ & 0.03 \\
\hline $\begin{array}{l}16 . \text { I find it } \\
\text { unnecessary in } \\
\text { my future } \\
\text { workplace }\end{array}$ & 0.03 & $\begin{array}{l}2.9 \\
9\end{array}$ & $\begin{array}{l}0.9 \\
0\end{array}$ & $\begin{array}{l}89.8 \\
2\end{array}$ & $\begin{array}{l}0.0 \\
0\end{array}$ & 0.00 & $\begin{array}{l}0.0 \\
6\end{array}$ & $\begin{array}{l}5.9 \\
9\end{array}$ & 0.01 \\
\hline
\end{tabular}


Note: 1-Strongly Disagree; 2-Disagree; 3-Undecided; 4Agree; 5-Strongly Agree

The table above shows that items No. 2 and 4 have the same percentage $(77.84 \%)$ in the scale of 4-Agree. This clearly shows that these two reasons affect the students to study the subject or language and having absence of the motivation. It cannot be denied that vocabulary is really related to the grammar that made these items become higher percentages of students' amotivation. This may be because the students know how important these two factors when communicating using the English language. And with this reason, the students find themselves cannot speak fluently (Item No.1) and having more lack of confidence in speaking (Item No. 10) that made it to the second highest reasons of agreeing in the scale. Also, items No. 3 \& 5 (with 0.60 average) that are nearly related to their knowledge in language become the third in the rank. As Nunan (1995, in Leong \& Ahmadi, 2017) mentioned that "the speaking skill is the most important aspect of learning a second or foreign language and success is measured based on the ability to perform a conversation in the language." This obviously means that the students get amotivated because of the inability of performing the conversation due to lack of knowledge in vocabulary and grammar that also affect them fluently, construct sentences, organize ideas and in the end have lack of confidence to speak In fact, these factors have also a higher number of average in Strongly Agree scale as item No. 3- "I cannot construct sentences" got 17.96 percentage and "I have lack of confidence in speaking" (item no. 10 in the second.

On the other hand, the students believed that they were not amotivated when it comes to activities and topics and do not even find the subject boring. As can be seen in the above table it ranks the top three in scale Strongly Disagree-1 with percentages $59.88,53.89$ and $47.90 \%$. This maybe because activities and topics in the said subject made them somehow motivated in studying the subject. As Redzuan et.al., (n.d.) mentioned that "students' preferred activities are another deciding factor that should be taken into consideration." Also, it can be noticed that students believe in the importance of learning the language by having top disagreement in item No. 15- "I find it no good reason to study the subject" following item no. 16 and 14. This means that these reasons cannot be their amotivation in learning the subject and language. As these students fully know that the language is needed in their chosen strand and in the future. It was suggested that "lack in English effects both in earning and occupational and mobility" (Kossoudji,1988) and "proficiency in English appears to be hindrance to secure a higher and a better paid position" (Schellekens, 2001) in Perinpasingam, 2015. On the other hand, only few students answered Scale 3-Undecided, this only shows that students really know what to answer in each item of their self-assessment in knowing their reasons of amotivation.

Structured Interview Questionnaire
Figure 1 presents the total percentages of respondents' preferred learning styles in learning oral communication/ English language.

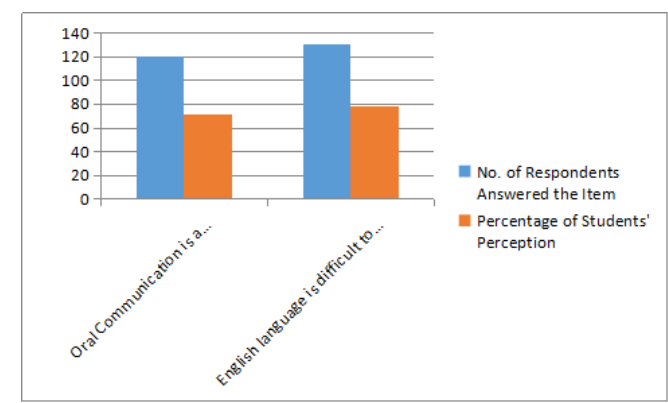

Figure 1: Percentage of Students' Preferred Learning Styles

The above figure (Fig.1) clearly shows that students admitted to themselves that Oral Communication subject and English language are both difficult to study. It can be shown that almost $75 \%$ of the students having a hard time to study the subject as well as the language for having almost it $80 \%$. This also proves in their own assessment as shown in the table above. Most of the students answered that they are experiencing problem in proper use of grammar, vocabulary, construction of sentences that eventually do not give confidence to speak or communicate. These three factors (grammar, vocabulary and pronunciation) are consider most important in building fluency. Thus, Tam (1997) suggested that "providing students with a variety of situations and frequent speaking tasks plays a significant role in the improvement of students' fluency when speaking (in Boonkit, 2010)." Aside from that it is a good factor that learners in their own are trying to improve their communication skills through watching and listening movies, internet and other social media functions. This also signifies that students still need to learn and train fully in speaking to communicate effectively. With this, the teacher may take consideration the suggested mode of activities by Morley (1991, in Nakagawa, n.d.) which may enhance students' speaking skill such as imitation, rehearsal and extemporaneous speech. These activities might be simple but would find interesting and helpful to the students especially when focusing to the four aspects of speaking such as fluency, accuracy, vocabulary and pronunciation.

Also, most of the students answered that because of these factors which fall more on their knowledge made them disinterested in studying the language. It is because most of them cannot express their ideas properly. In fact, most of the students answered that they do not want the impromptu speech activity because it requires them to speak on the spot. In can be suggested the six (6) strategies of Tsui and her teachers (in Nunan, 2009) for overcoming anxiety and reluctance to speak. These are: to lengthen the amount of time between asking a 


\section{International Journal of Engineering Applied Sciences and Technology, 2020 \\ Vol. 5, Issue 4, ISSN No. 2455-2143, Pages 101-107 \\ Published Online August 2020 in IJEAST (http://www.ijeast.com)}

question and nominating someone to respond, to improve questioning techniques, to accept variety of answers, to give learners an opportunity to rehearse their responses in small groups or pairs before being asked to speak up in front of the whole class, to focus on content rather than form, and to establish good relationships with the students, On the other hand, some of them answered that good ventilation and good atmosphere somehow affects them not listen to the class and made them disinterested in studying during the class. Kounin (1970, p.63) defined "effective classroom management as producing a high rate of work involvement and a low rate of deviancy in academic settings. It includes the provisions and procedures necessary to establish and maintain an environment in which instruction and learning can occur and the preparation of the classroom as an effective learning environment (Fraser, 1983, p.68) in Lim, et. al., 2003. This may not be seems to be related in the knowledge factors that made them amotivated in learning the subject/ language but still one important thing to consider for the students. Thus, this factor cannot be eliminated in the interest of the students to study.

It is also good to know that most of the students answered that for them to be able to cope up with their subject is just to simply comply with the requirements. With this reason in their mind, it is therefore can be fall into instrumental motivation. The students learn the subject just because it "desire to obtain something practical or concrete from the study of second language (Hudson, 2000, in Redzuan, n.d.).

It is also not quite new that students' preferred learning style or own style shall be considered in teaching the language. With this, among 167 students, there were 102 students answered that they just simply reading books, watch movies using English language and vlogs (which are now more interesting to the youth). Some were also taking down notes during the class, there are taking the down the words that are new to them to be able to check the meaning of it. This somehow helps them to improve their vocabulary.

\section{CONCLUSION AND RECOMMENDATIONS}

It cannot be denied that important factors in communicating or speaking such as pronunciation, grammar and vocabulary made the learners to speak diffidently. There were also a lot of techniques, methods and approaches have already tried by the teachers when teaching speaking. In fact, there were a lot of studies already suggested the best and latest techniques and approaches for the same problem. Unfortunately, the same issues occur and still problematic as such in these students.

Thus, with these top factors that made students amotivated in learning the subject and language, the researcher suggested explicit teaching through a formal presentation of grammatical rules and implicit teaching through natural exposure to meaningful language use in teaching grammar (Nassaji \& Fotos, 2011). Also, an intuitive-imitative and analytic-linguistic approaches were suggested above when teaching pronunciation. Whereas, intuitive-imitative is where "L2 learners listen and imitate the rhythms and sounds of an L2 without any explicit instruction". This can be done by taking advantage of the technologies such as audiotapes, videos, computer-based programs and web sites, While analytic-linguistic approach is where "L2 learners are provided with explicit information on pronunciation such as phonetic alphabet, articulatory descriptions, and vocal charts" (Celce-Murcia, Brinton \& Goodwin, 1996 in Hashemian \& Fadaei, 2011). An integrative approach may also use by the teacher where pronunciation is being practiced through meaningful task based activities (Lee, 2008 in Hashemian \& Fadaei, 2011). Lastly, it was mentioned by Mehta (2009) that translation of the word is not the best way of teaching vocabulary instead by integrating activities that is depend on level of understanding and ability of the learners.

It was also mentioned that the practice and application of the knowledge inside the classroom should also need to consider (Iakovaki, n.d., p.6). The pragmatic competence is highly recommended for the learners to be trained well and confidently speak using the language. It is also important to note that "interaction" is also need to consider in having the students learn the language and improve one's speaking ability. Classroom interaction may help learners to get comprehensible input and feedback from their partners (Mckay \& Schaetzel, 2008). This is the students' opportunity to give feedback and comment immediately with the speaker and later on find out the appropriate use of the language. This may also serves as the students' actual practice and application of their required language. Teaching speaking is quite challenging for the teachers especially in considering the factors that is required to the students to learn and improve. According to Kayi (2006), communicative language teaching and collaborative learning are the best teaching techniques in speaking where the students engaged into a reallife communication and authentic activities.

It is also important to consider the students' preferred learning styles in studying the language. The learners' own techniques and strategies in learning the language should be considered and given opportunity by the teachers to the learners.

"Technology causes students to be more engaged; thus, students often retain more information" (Costley, 2014). As mentioned above, it was also found out that students' way of learning the subject and language is by watching movies and vlogs. Therefore, teachers must also consider these things inside the classrooms and take advantage of the technology. Most of the students nowadays, easy to learn because of what seems them more interesting. Thus, using technology is well recommended not only during discussion but also in their activities or task inside the classroom. "Students today live in a very technological world. Most students use some form of technology on a daily basis including; texting, social networking, and web surfing. Students see these types of 


\section{International Journal of Engineering Applied Sciences and Technology, 2020 \\ Vol. 5, Issue 4, ISSN No. 2455-2143, Pages 101-107 \\ Published Online August 2020 in IJEAST (http://www.ijeast.com)}

technologies as useful and extremely enjoyable" (Costley, 2014). This would definitely engage them more and become more interested in studying.

Thus, teachers, syllabus and curriculum designers are suggested to focus on different approaches and strategies that would engaged students into a more authentic and having real activities when teaching speaking. Students nowadays, can be identified as "actual learners" - where they can easily understand and learn the language if they are expose on it and actually experiencing it. It is also highly recommended to use both traditional and conventional strategies of the teachers; at the same time considering students' own way of learning the language. "Behaviors used by language learners to enhance the acquisition, storage, retention, recall, and use of new information" (Oxford 1990:36 in, Gill, 2005)" and also believes that the combination of these approaches and strategies both teachers' and learners' goal for all students in learning the language and speaking confidently would successfully achieved.

\section{REFERENCE}

[1] Boonkit, K. (2010). Enhancing the development of speaking skills for non-nativespeakers of English. Science Direct. Elsevier Ltd. Retrieved from: http://ac.elscdn.com/S1877042810002314/1-s2.0-

S1877042810002314-main.pdf?_tid=e681ff60-9748$11 \mathrm{e} 7-\mathrm{a} 080$

00000aacb362\&acdnat=1505172689_aead53b78a71f ed9093f58e0ee4e0014

[2] Costley, K. (2014). The Positive Effects of Technology on Teaching and Student Learning. Research Gate. Retrieved from: https://files.eric.ed.gov/fulltext/ED554557.pdf

[3] Gil, D. (2005). Meeting Differing Learning Styles Of Non-traditional Students In The Second Language Classroom. Journal of College Teaching \& Learning. August 2005. Volume 2, Number 8 1. Retrieved from: https://www.cluteinstitute.com/ojs/index.php/TLC/article/ view/1848/1827

[4] Hashemian, M. \& Fadaei, B. (2011). A Comparative Study of Intuitive-imitative and Analytic-linguistic Approaches towards Teaching English Vowels to L2. Vol.

Learners Journal of Language Teaching and Research,

2, No. 5, pp. 969-976, September 2011. Retrieved from: http://www.academypublication.com/issues/past/jltr/vol02/ 05/04.pdf

[5] Iakovaki, H. (n.d.). Building the intercultural dimension in new learning tools for seafarers: the captain's platform for maritime English. Special Academic Session: Cultural Diversity \& Maritime Human Resources Management. Retrievedfrom: http://www.deepdyve.com/lp/indersciencepublishers/new-curriculum-for-the-seafarers-of-the-newera-building-the-0ZZ9W13MwX

[6] Idrissova, M., Smagulova, B. \& Tussupbekova, M.(2015).
Improving listening and speaking skills in mixed level groups (on the material of New English File). Science Direct. Elsevier Ltd. Retrieved from: http://ac.elscdn.com/S1877042815045280/1-s2.0

S1877042815045280-main.pdf?_tid=8a5488b8-975f-11e797a7-

00000aacb35f\&acdnat=1505182405_d88363b034888f8d6a $19 \mathrm{eb} 2189291 \mathrm{~d} 09$

[7] Kayi, H. (2006). Teaching speaking: activities to promote speaking in a second Language. The Internet TESL Journal, Vol. XII, No. 11, Retrieved from: http://iteslj.org/Articles/Kayi-Teaching Speaking.html

[8] Leong, L. \& Ahmadi, S. (2017). An Analysis of Factors Influencing Learners' English Speaking Skill.

International Journal of Research in English Education. Retrieved from:

http://ijreeonline.com/files/site1/user_files_68bcd6/eng/sm a1357-A-10-26-1-fefa0eb.pdf

[9] Massouleh, N. \& Jooneghani, R. (2012). Needs analysis: ESP perspective on genre. Journal of Education and Practice. Vol 3 No 6. Retrieved from: http://www.iiste.org/Journals/index.php/JEP/article/view/1 638

[10] Mckay, S. \& Schaetzel, K. (2008). Facilitating adult learner interactions to build listening and speaking skills. CAELA Network. Central for Applied Linguistics. Retrievedfrom:http://www.cal.org/caelanetwork/pdfs/Lea rnerInteractionsFinalWeb.pdf

[11] Mehta, N.(2009). Vocabulary Teaching: Effective Methodologies. The Internet TESLJournal, Vol. XV, No. 3, March 2009. Retrieved from:

http://iteslj.org/Techniques/Mehta-Vocabulary.html

[12] Lucas, R. et.al. (2016). Amotivation in Filipino ESL Learners: Exploring Some Correlates. Research Gates. Retrieved from: https://www.researchgate.net/publication/309666634_A motivation_in_Filipino_ESL_Learners_Exploring_Some _Correlates

[13] Nakagawa, K. (n.d.) Teaching speaking: from accuracy vs. fluency to accuracy plus fluency. Retrieved from: http://www.geocities.co.jp/Berkeley/9546/papers/paper2. htm

[14] Nassaji, H. \& Fotos, S. (2011). Teaching Grammar in Second Language Classrooms: Integrating Form-Focused Instruction in Communicative Context. New York. Routledge, 2011. Pp. ix+167. Retrieved from: https://www.asian-efl-journal.com/teaching-grammar-insecond-language-classrooms-integrating-form-focused-. instruction-in-communicative-context/

[15] Perinpasingam, P. (2015). Needs Analysis on the Importance of English Language Skills for Workplace: Trainee Architects Article. Retrieved from: https://www.researchgate.net/publication/317248121_Ne eds_Analysis_on_the_IImportance_of_English_Languag e_Skills_for_Workplace_Trainee_Archite 
[16] Qashoa, S. (2006). Motivation among Learners of English in the Secondary Schools in the Eastern Coast of the UAE. Asian Journal EFL. Retrieved from: https://www.asian-efljournal.com/thesis_Sulaiman_Hasan_Qashoa.pdf

[17] Redzuan, N. et.al. (n.d.). English Language Learning: A Survey of Motivation and Preferred Activities among Engineering Students in Polytechnic Students in Polytechnic Kuching Sarawak. Journal of Techno Social. Retrieved from:

https://publisher.uthm.edu.my/ojs/index.php/JTS/article/v iew/1421

[18] Shirbagi, N.(2010). An Exploration of Undergraduate Students' Motivation and Attitudes towards English Language Acquisition. Journal of Behavioural Sciences. Retrieved from:

https://www.semanticscholar.org/paper/An-Explorationof-Undergraduate-Students- $\%$ E2\%80\%99-and-

Shirbagi/cf4ad626018b74ae88f23c1e39334ea8ef539898 